Michael Kohs, Giuseppe Veltri

\title{
Magic in the Hebrew-Manuscript Collection of the Staats- und Universitätsbibliothek Hamburg: Observations on Cod. hebr. 252
}

\begin{abstract}
The Staats- und Universitätsbibliothek Hamburg holds several Hebrew multiple-text manuscripts of Jewish magic that until now have received only occasional scholarly attention. This paper focusses on Cod. hebr. 252, a seventeenthcentury manuscript of Jewish magic from the Hamburg collection. The codex is in a fragmentary state, making a reconstruction of its history difficult. Evidence suggests that the codex was originally produced in Northern Italy and later came to the German lands. The manuscript's original, main content consists of magical recipes and instructions, magical-mystical names, cosmological diagrams, and astronomical drawings. This content has then been supplemented with additional magical texts as well as with various items of paracontent and guest content.
\end{abstract}

\section{Introduction}

The collection of Hebrew manuscripts held by the Staats- und Universitätsbibliothek 'Carl von Ossietzky' in Hamburg (Stabi) is one of the three most important collections of Hebrew manuscripts in Germany, with regard to both the quantity and the cultural significance of the manuscripts. ${ }^{1}$ In this respect the Stabi's collection is of equal standing with the collections of the Staatsbibliothek zu Berlin and the Bayerische Staatsbibliothek in Munich. The vast majority of the manuscripts already belonged to the library when the Stabi emerged from its predecessor, the Stadtbibliothek Hamburg, in 1921. Most of the Hebrew manuscripts held by the Stabi are divided into two groups of shelf marks: 'Cod. hebr.' ${ }^{2}$ and 'Cod. Levy'. ${ }^{3}$ Most of the items bearing the 'Cod. hebr.' shelf mark

1 For a more extensive history of the collection, see Stork 2014; Steinschneider 1969, V-XIII; and Róth and Striedl 1984, IX-XIX.

2 Codices hebraici, 'Hebrew manuscripts'. The manuscripts up to Cod. hebr. 337 have been catalogued by Moritz Steinschneider; see Steinschneider 1969 (originally published in 1878). This shelf-mark group, which remains open for new acquisitions, today comprises more than 350 manuscripts. 
came to the Stadtbibliothek from the manuscript collection of Johann Christoph Wolf (1683-1739). ${ }^{4}$ Wolf had bought several collections of Hebrew manuscripts, the largest being the collection owned by Zacharias Konrad von Uffenbach (1683-1734). ${ }^{5}$ The manuscripts bearing the 'Cod. Levy' shelf mark were bought as a whole by the Stadtbibliothek from the private collection of Heyman Baruch Levy in $1906 .^{6}$

Both shelf-mark groups of Hebrew manuscripts comprise various items that contain kabbalistic texts as well as material that can be classified as magical or as practical Kabbala. ${ }^{7}$ In many cases it may be difficult to speak of 'manuscripts of magic' or 'magical manuscripts': often purely magical texts are included in manuscript that contains kabbalistic treatises or other genres. Or magic is only a side note in the manuscript, such as when magical recipes are added in empty spaces or on blank pages at the end of a manuscript, thus giving such recipes the status of guest texts. Generally speaking, manuscripts that contain only magical texts in the strict sense, from beginning to end, are a minority.

In research on written artefacts of Jewish magic, a general distinction between 'finished products', which are attributed a direct magical efficacy (i.e. amulets), and 'instructional texts' has been established. ${ }^{8}$ The latter are recipes, formulas to be recited, instructions for the preparation of amulets, or model forms to be copied in the production of an amulet. Instructional texts, usually termed segullot in Hebrew, ${ }^{9}$ are often part of a larger collection of magical texts

3 Codices Levy, catalogued by Róth and Striedl 1984.

4 On Johann Christian Wolf, see Mulsow 2005; on Wolf and Hebrew literature, see especially pp. 97-99. Wolf was the author of the bibliographical work Bibliotheca Hebraea, which was published in four volumes from 1715 to 1733 (Wolf 1727).

5 On Zacharias Konrad von Uffenbach and his collections, see Friedrich and Müller 2020. A catalogue of 141 Hebrew manuscripts in Uffenbach's collection was published by Mai 1720, 1-416. 6 See Róth and Striedl 1984, IX-XIX.

7 The distinction between Kabbala as a mystical or theosophic discipline on the one hand and magic on the other is not in every case easy to make clear. See Harari 2019 on the relationship between magic and Kabbala and on the concept of magic as practical Kabbala. We stick to the term 'magic' since it has become established as a heuristic concept in the scholarly community working on these phenomena in the context of Judaism; see, e.g. Bohak 2008 and Harari 2017. 'Magic' designates a group of practices that, while they share certain family resemblances, are not amenable to a common definition; nevertheless the proposals for such a definition usually involve relationships of cause and effect; cf. Otto and Stausberg 2013, Veltri 1997, 18-22 and Veltri 2012, 237-240.

8 See Harari 2017, 207-216 and Bohak 2008, 143-148.

9 Segulla (plural segullot), lit. '(precious) property'; in the context of Jewish magic, the term segullot originally designated inherent properties of objects or materials (such as plants or gemstones) that induce an efficacy that could be utilized for magical purposes. The word 
contained in a multiple-text manuscript (henceforth MTM).$^{10}$ Although there are some established and commonly known text collections of magic or practical Kabbala, many Jewish MTMs that concern magic are more or less individual compilations of often rather short textual units, arranged by the scribe according to his individual needs and interests. In such cases, cataloguers often could not do more than label these passages or complete manuscripts as segullot or refu'ot. ${ }^{11}$ Cataloguing down to the level of individual recipes is usually not the purpose of a catalogue of a manuscript collection. The academic study of magic, on the other hand, would profit tremendously from more detailed accounts of magical texts in manuscript catalogues.

Scholarly research on the magical manuscripts in the Hamburg Hebraica collection started at the end of the nineteenth century. Max Grunwald (18741953), who served as a rabbi in Hamburg from 1895 until 1903 and who was a scholar of Jewish folklore ('Jüdische Volkskunde'), was familiar with the manuscripts in what was then the Stadtbibliothek, and he refers to them in several publications. ${ }^{12}$ In the 1990s and 2000s, two Hamburg manuscripts were studied in research projects on Jewish magic conducted at the Freie Universität Berlin: Cod. hebr. 136 was included by Rebiger and Schäfer in their edition of the magical manual Sefer ha-Razim; ${ }^{13}$ and the manuscript Cod. hebr. 156 was identified as an important textual witness to the transmission of another magical handbook, the Sefer Razi'el ha-Mal'akh. ${ }^{14}$ And in 2014, in cooperation with the Centre for the Study of Manuscript Cultures at the University of Hamburg, the Stabi assembled seventy-eight items from its collection of Hebrew manuscripts for an

segulla then developed into a technical term for 'magical recipe' or 'magical instruction' in general.

10 A multiple-text manuscript (MTM) contains more than one main textual unit. An MTM can consist of one or more codicological units, in which case it is termed a composite manuscript. We use the term MTM instead of the ambiguous expressions miscellany or Sammelhandschrift. On MTMs and their phenomenology, see Friedrich and Schwarke 2016, in particular the introduction by the editors 1-26, and Bausi, Friedrich and Maniaci 2019.

11 Refu'ot 'healings' are segullot for the purpose of healing illnesses and ailments.

12 For instance, Grunwald refers to Cod. hebr. 222, 296, and 318 in Grunwald 1898, 80 in the context of childbirth amulets; and to Cod. hebr. 135, 166, 175, 251, and 296 in Grunwald 1900. On Max Grunwald, see Daxelmüller 2010; on Jüdische Volkskunde in general, see Johler and Staudinger 2010 and Veltri 1997, 11-12.

13 See Rebiger and Schäfer 2009, vol. 1, 19 et passim.

14 See Rebiger 2005 and the extensive discussion about the broader context of the transmission of Sefer Razi'el ha-Mal'akh in Leicht 2006, 187-294. 
exhibition. ${ }^{15}$ Besides two amulets, the section on Kabbala and magic featured seven MTMs with magical recipes and mystical-kabbalistic treatises as well as mystical prayer books. ${ }^{16}$ Apart from this small number of publications, however, the Hebrew manuscripts from the Staats- und Universitätsbibliothek Hamburg have not been a focus of scholarship on Jewish magic and ought to be regarded as a treasure that awaits discovery.

\section{Cod. hebr. 252}

With this paper, we would like to contribute to discovering this treasure by taking a closer look at one specific MTM of Jewish magic: Staats- und Universitätsbibliothek Hamburg, Cod. hebr. 252. Before it came to the library via Johann Christoph Wolf, the manuscript was part of the collection of Zacharias Konrad von Uffenbach and was described by Johann Heinrich Mai in his catalogue of the Uffenbach collection. ${ }^{17}$ A Latin description of the content of the manuscript and the exlibris of von Uffenbach, depicting an ideal library that covers all the arts and sciences, have been pasted on the inner front cover (Fig. 1). In Hamburg the manuscript was catalogued in the 1870 s by Moritz Steinschneider, whose entry on it is the only existing scholarly account of this codex. ${ }^{18}$ We are not aware of any other published research dedicated to this manuscript. ${ }^{19}$ Interestingly, the entry - about a page long - occupies more space than many other manuscripts in Steinschneider's catalogue. Starting from Steinschneider's entry and considering the various manuscriptological features of Cod. hebr. 252namely, codicology, paracontent, core-content, and guest content - we intend to shed more light on the history of the manuscript - which Steinschneider, on palaeographic grounds, dates to the seventeenth century ${ }^{20}$ - as an example of

15 'Tora - Talmud - Siddur. Hebräische Handschriften der Staats- und Universitätsbibliothek Hamburg, 18. September-26. Oktober 2014'. See Wandrey 2014 for the accompanying catalogue.

16 See Wandrey 2014, 281-308.

17 Mai 1720, 408-416, no. CXLI. The description of the manuscript by Johann Christoph Wolf in his Bibliotheca Hebraea (see Wolf 1727, 799-800, no. 24) is to a large extent, as Steinschneider 1969, 99 notes, a direct excerpt from Mai.

18 See Steinschneider 1969, 99-100, no. 248.

19 Except for brief mentions by Grunwald, Trachtenberg, and Scholem; see below. The references by Trachtenberg and Scholem are apparently based on their study of Steinschneider's catalogue only.

20 Steinschneider 1969, 99. 
early modern Jewish MTMs with magical content. However, due to limitations of space, we will have to restrict ourselves to selected aspects of this codex.

\subsection{Codicology}

In its current state, Cod. hebr. 252 comprises 33 folios made of paper and measures 20.1 centimetres in height and 15.5 centimetres in width. Because Mai reports the number of folios as $57,{ }^{21}$ we must recognize that a substantial loss of folios has occurred. Moreover, the original quire structure of the manuscript has been destroyed in the course of time. The manuscript begins with two bifolia. The first bifolium (fols 1-2) contains a page with probatio pennae and biblical quotations (fol. 1a) (Fig. 1), a poem alluding to Sabbatai Zevi (fol. 1b) (Fig. 2), and a page containing a title (fol. 2a). The second bifolium (fols 3-4) contains on fol. $3 a-b$ texts that are numbered from 86 to 95 and on fol. 4 a childbirth amulet on the recto and a segulla against a storm on the verso, both added later by hand $\mathrm{C}$. The first actual quire, a senion, begins with fol. 5 , which is blank (fols 5-16). It can be supposed that this quire retains its original structure and that the entire manuscript originally composed of senions. ${ }^{22}$ From folios $6 \mathrm{a}$ to 18a, the texts are numbered from 191 to 226. So at least two additional senions must have come before what is now the first senion. The senion which is still extant is followed by a single bifolium (fols 17-18). ${ }^{23}$

The only continuous foliation is in a modern hand and was added in 1876 in the process of cataloguing, maybe by the cataloguer Moritz Steinschneider himself during his stay in Hamburg in July of the same year. ${ }^{24}$ The folio numbers that we cite in our paper refer to this nineteenth-century foliation in Arabic numerals, with pencil. On three pages, remains of an older foliation in Arabic

21 See Mai 1720, 408. Mai prints excerpts from what were then fols 10b, 11a, 14a, and following.

22 Among medieval Hebrew paper manuscripts until 1500, one quarter of the Italian and almost half of the Sephardic codices were composed of senions; see Beit-Arié 2020, 321. As the research on the codicology of early modern Hebrew codices is still at its beginnings, we do not know to what extent senions are typical for this era.

23 We have been unable to determine the exact quire structure after this bifolium. A thorough autopsy of the manuscript in situ was impeded by the Corona pandemic. Mai 1720, 409, mentions that after the last numbered text (on today's fol. 17b), eleven folios without text numbering followed.

24 See Steinschneider 1969, VIII, XII n. 11, and XIV. 
numerals in ink can be found (Fig. 7). ${ }^{25}$ Most of this older foliation probably became the victim of page trimming.

Several verso pages of the collection are blank or were once blank before a different hand added text to them. Interestingly, mostly versos of folios that contained some kind of diagram or drawing on their recto side were originally left blank. ${ }^{26}$ Other parts of the manuscript contain a number of blank pages (fols 20b-23a and fols 25b-31a).

\subsection{General content and palaeography}

The manuscript's primary content consists of a collection of segullot (i.e. magical recipes and instructions), magical-mystical names, cosmological diagrams, and astronomical drawings by an Italian hand (hand A). ${ }^{27}$ The texts of this collection are numbered by Hebrew letters in the margins and extend, with gaps, from fol. 3a through fol.18a. Inserted between these texts or added after them, there are magical texts by different Sephardi hands; these inserted texts are not included in the Hebrew numbering of the primary texts. ${ }^{28}$ Folios 23b-25a contain an alchemical text in Spanish written in Hebrew characters by another, distinct Sephardi hand (hand F). Additional content includes poems referring to Sabbatai Zevi and lists with names of towns and persons; presumably both the poems and the lists are by the same hand. ${ }^{29}$ Codex hebr. 252 thus represents different geo-cultural variants of Jewish manuscript cultures, especially with regard to palaeography. ${ }^{30}$ From the mere type of script, however, one cannot always directly infer the geographic provenance of a manuscript. ${ }^{31}$ Throughout the codex, the various hands use Hebrew square script or semi-square script for writing magical or angelic names, whereas all other parts of the texts, e.g. passages with instructions, are written in a cursive or semi-cursive script.

25 Folios 19-21 (new) are marked as 49-51 (old).

26 This concerns fols $7,9,12$, and 13 . Folio $8 \mathrm{~b}$ was also originally empty; its content was added later by hand $\mathrm{D}$. The recto features a cosmological diagram, which was part of the original production plan and is labelled as text no. 193.

27 Besides Italian palaeographic features, hand A also exhibits Sephardic traits, though it differs significantly from all the unambiguously Sephardic hands in the manuscript.

28 Hand C: fols 4a-b; hand D: fols $6 \mathrm{~b}$ (lower half of page); 8b, 18b-19a; hand E: fol. 16b.

29 Hand B: fols $1 \mathrm{~b}, 32 \mathrm{~b}, 33 \mathrm{~b}$. The hands B, C, and E are possibly the same scribe.

30 On the geo-cultural variants of Jewish-Hebrew manuscript culture (Ashkenazic, Italian, Byzantine, Sephardi and Oriental), see Beit-Arié 1993a, 25-37.

31 Script type and style are usually individual characteristics that persist when a scribe migrates to other regions. See Beit-Arié 1993b, 34-35. 
This way of highlighting magically effective textual material is common for most manuscripts that contain Jewish magical material.

\section{Paracontent}

\subsection{Folio 1a: Probatio pennae}

Folio 1a gives the impression of having been used for writing exercises or probatio pennae (Fig. 1). The writing is mostly executed in square script, some of it quite large, and some of the text on the bottom of the page is vertically aligned. In places, the square script used here bears features of the ktav stam, i.e. the variants of the Hebrew script that are used to write sacred and liturgical manuscripts such as Tora scrolls, tefillin, and mezuzot..$^{32}$ Only a small number of other notes on the page are in cursive script. ${ }^{33}$ There are no columns and no defined areas for writing.

The uppermost line consists of the letters of the Hebrew alphabet, including the allographs for five letters that have a different final form. Directly below we find a short quote from a Talmud passage that extensively discusses the shapes of the letters of the Hebrew alphabet and the meaning and importance of their divergent final forms. ${ }^{34} \mathrm{~A}$ number of biblical verses are cited on this page. ${ }^{35}$

32 Among these features are the tagin 'crowns', which are added on the top of certain letters and the 'broken' upper bar of the letter het, making the het look like two joined zayyin letters. On this folio only few words are written with these features, e.g. the name Ahasuerus and 'Hear, O Israel!' These tagin are not executed in the correct, traditional way. Neither is every letter that would require it written with tagin; nor is the number of tagin per letter correct. On tefillin and mezuzot, see below.

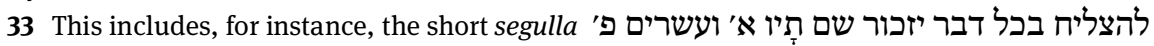
'To succeed in everything: Say the name tav twenty-one times. Tested and tried.' Further scientific material analysis is required to determine whether some of the cursive writing is from a different scribe than the scribe responsible for the square script. Also, the cursive inscriptions themselves are most likely from two different hands.

34 Babylonian Talmud, Tractate Shabbat 104a: מנצפך צופים אמרום 'the seers [i.e., prophets] called them Mem, Nun, Tsade, Pe, and Kaf [i.e., the final forms of these letters]'.

35 As is common in the Jewish tradition, not the whole verse but only a single word or a few words are cited. The verses cited are (from top to bottom and from left to right): Psalm 17:7 וDisplay Your faithfulness in wondrous deeds, You who deliver with Your right ויהי במי אחשורש הוא אחשורש 1:1 מים 'It happened in the days of Ahasuerus - that Ahasuerus who reigned [over a hundred and twenty-seven provinces] from India to Ethiopia.'; Deuteronomy 6:4 
Although they appear to be probatio pennae, the verses that the one or more owners or scribes chose to cite are surely not arbitrary. The biblical and talmudic citations gathered on this initial page of the manuscript reveal three aspects of Judaism which seem to have been of importance for the scribe(s). The first is the Hebrew alphabet, the Hebrew script, and the writing of sacred manuscripts. The Talmud passage about the final forms of five letters of the Hebrew alphabet and the citation of Psalm 45:2 directly invoke writing practices. Secondly, some of the verses cited relate to central symbols of Judaism: Deuteronomy 6:8-9 is the basis for several mitsvot, commandments from the Tora, that observant Jews are obligated to fulfil. These mitsvot explicitly involve manuscripts and were already mentioned above: the use of tefillin, phylacteries worn on the left arm and on the forehead during the morning prayer, and the mezuza, a small oblong container attached to doorposts. ${ }^{36}$ These first two aspects of Judaism highlight the importance of writing - or manuscript practices in general - in the practice of Judaism. Thirdly, the initial page cites biblical verses that, on the one on hand, allude to Jews or the Jewish people in distress, such as when they were threatened by persecutors (Book of Esther) or by famine (Book of Ruth) and, on the other hand, emphasize God's everlasting grace and protection for the people of Israel (Psalm 121:4). This dual focus might reflect dangers that the scribe sensed for himself, his family, or the Jews of his time and region.

The content of this page thus evinces an interest in legitimization and selfassertion. The scribe - who is not necessarily identical with the scribe of the manuscript's primary texts - presents himself as a pious Jew. The allusions to religious practices and manuscripts (by citing biblical verses) and the features of the ktav stam (the script that is used for sacred writings) extend their sacredness to the magical texts found in this manuscript. The page serves as a

שומר 121:4 'Hear, O Israel! [The LORD is our God, the LORD alone.]'; Psalm '[See,] the guardian of Israel [neither slumbers nor sleeps!]’; allusions to Deuteronomy

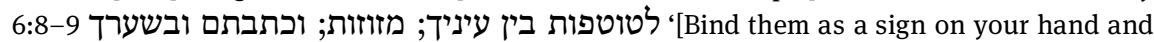
let them serve] as a symbol on your forehead [;] inscribe them [on the] doorposts [of your house] and on your gates.'; Ruth 1:1 שפוט השופטים '[In the days when] the chieftains ruled [,

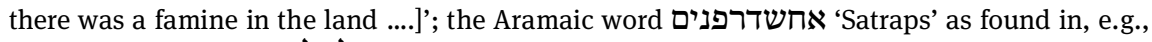
Esther 8:9; Psalm 45:2 אומר אני מעשי למלך 'My heart is astir with gracious words;] I speak my poem to a king; [my tongue is the pen of an expert scribe.]' All English translations of biblical verses are based on Tanakh 1985.

36 Both the tefillin and the mezuza contain small slips of parchment with short passages from the Tora, including Deuteronomy 6:4, which is also found on our page and which is the beginning of the Shema Yisrael, one of the central Jewish prayers, with a fixed place in the Jewish liturgy. 
reassurance that the scribe as well as potential readers are pious and observant and that reading and using these texts is well within the permitted realms of the Jewish religion. ${ }^{37}$

\subsection{A new title page}

Because it contains lower text numbers (86-95) than the senion consisting of fols 5-16 (beginning with text no. 19 on fol. 6a), we may conclude that the second bifolium (fols 3-4) was once part of one of the quires preceding this senion. The original position of what is now the first bifolium is less clear. Folio 2a features a supposed title ספר הקבלה מהרב רבי משה בר נחמן צז"ל, 'Book of Kabbala by the teacher Rabbi Moshe bar Nahman, may the memory of the righteous be blessed' (Fig. 2) ${ }^{38}$ As already noted by Steinschneider, this title obviously ספר was once an explicit, or the final words of a work: right before the word 'book', the word נשלם 'finished [is]' has been erased, with resulting damage to the paper. What was originally a closing formula has been turned into a title and is therefore placed slightly off-centre on the page. Since the explicit is still quoted as such by Mai, the reworking of the codex must have been done at some time after Mai wrote and before Steinschneider got hold of the manuscript. Maybe the page with the explicit was shifted to a front position (now fol. 2) as a means of coping with the removal of a vast number of folios and the destruction of the original structure of the codex. In the stage of the manuscript as described by Mai, however, this folio was already placed not at the end of the codex but in the middle, as fol. $15 .^{39}$

37 A comparable page with quite similar functions can be found in the sixteenth-century manuscript of Yoseph Tirshom's compendium of magical and mystical texts, Shoshan Yesod ha-Olam, Geneva, Library of Geneva, Comites Latentes 145, p. 21; see Kohs 2016 on this manuscript.

38 Moshe b. Naḥman, (1194-1270), also RaMBaN or Naḥmanides, lived in Spain and was one of the most renowned Jewish thinkers of the Middle Ages. The attribution of this 'Book of Kabbala' to him is, of course, pseudepigraphic. Such an ascription, which is by no means an isolated case, is stimulated by Nahmanides' interest in mysticism and theurgy; see Schwartz 2005, 56-90 on these aspects of his authentic work.

39 Mai 1720, 408, comments on the position of the explicit: 'Sic enim legimus folio XV. quod ultimum esse debet totius libri, sed a bibliopeia traiectum est'. 


\subsection{Text numbering and an index on fol. $20 \mathrm{a}$}

Just as the manuscript does not contain an original title page, neither does it feature an index or a table of contents. Nevertheless, the Hebrew numbering of the texts, i.e. the structure provided by the arrangement of the segullot themselves, was probably part of the original production plan. This numbering resembles hand A and only appears with texts written by hand A. The numbering of texts in the main parts of the manuscript suggests that a navigation system using the text numbers as references, such as an index, was present in the original stage of the manuscript yet is now lost. Folio 20a, however, contains a short list of purposes for segullot and their respective text numbers. The folio itself has only half the width of the other folios of the codex. The list, which was written by an Ashkenazi hand that is not identical with any other hand in the codex, contains eleven items. Only one entry refers to a text that is still to be found in the manuscript: לשתות ולא ישתכר בסימן צ"א To drink without getting drunk: at sign [i.e. number] 91'. The text referred to is found on the top of fol. 3b, although here it is assigned the number 90 (Fig. 3). The list may thus be a trace of an owner or user of the manuscript who singled out those texts from the manuscript that were of interest to him. Besides 'drinking and not getting drunk', he chose segullot for success, especially in business matters, and against forgetfulness.

\subsection{Abraham Mercado}

On fol.9b, which is otherwise empty, we find the name Abraham Mercado in-

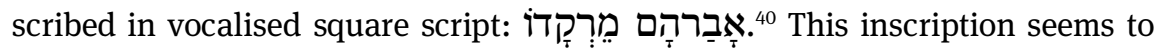
be secondary, i.e. later than the main text. Steinschneider lists Abraham Mercado as a manuscript owner of Cod. hebr. 252 in the index of his catalogue. ${ }^{41}$ The name Mercado could be a family name: Mercado or de Mercado has long been a common Spanish family name among Jews. ${ }^{42}$ However, a verifiable identification of the name Abraham Mercado with a specific person, for instance with the

\footnotetext{
40 The vocalisation of the name Abraham, however, is anomalous and would have to be pronounced Avarham. The standard form would be אַבְרָהָ Avraham.

41 Steinschneider 1969, 209.

42 See Guggenheimer and Guggenheimer 1992, 189.
} 
well-known, seventeenth-century Sephardi physician Dr Abraham de Mercado or his family, ${ }^{43}$ seems rather unlikely.

Alternatively, if taken literally, according to its meaning in Spanish as 'market' or 'purchased', the name Mercado may be evidence of an apotropaic custom: when a mother lost a child, it was assumed that bad fortune was clinging to her. In order to protect the children that would be born to her later, they would be sold symbolically to other parents and receive a byname relating to this sale. Among the Sephardim, the Jews in the Spanish tradition, Mercado or Mercada was the common byname connected with this practice..$^{44}$ Because the codex offers no further paratextual information about the name, we cannot decide whether Mercado is to be taken as a family name or as evidence of this apotropaic custom.

\section{Core-Content}

\subsection{A bilingual Italian-Hebrew spell}

On fol. 17b, at the very end of the passage with numbered texts, we find at the bottom of the page a bilingual love spell, presumable written by hand A (Fig. 4). In the text, Italian in Latin script and Hebrew in Hebrew script are used alternately:

$\begin{array}{ll}\text { Transcription }{ }^{45} & \text { Translation } \\ & \text { For [Love/struggling]. There is none like it. Take } \\ \text { filo che non sia tento } & \text { a hair which is neither black } \\ \text { Ni bianco di una putta Vergiene }{ }^{47} & \text { nor white from a virgin girl. }\end{array}$

43 On the Mercado family, whose members lived in Dutch Brazil, various places in Europe, and Barbados, see, e.g. Schreuder 2019, 150, 185-186, 192.

44 See Ben-Ami 2003, 185; Guggenheimer and Guggenheimer 1992, XVII-XVIII, 509; and Kaganoff 2005, 103-104. On an actual case of this apotropaic practice, see below, chapter 4.4.

45 The transcription offered by Steinschneider 1969, 100 is erroneous. We thank Saverio Campanini (Bologna) for his help in reading this segulla.

46 is probably a scribal error and a metathesis of לאהבה 'for love'. One could also read לקאבק להאב rfor struggling'. Steinschneider reads להאבר which makes no sense.

47 See Malavasi 2005, 198, where another putta vergiene, 'virgin girl', is mentioned in Italian magic. 


\author{
ועשה ל"ג קשרים בידך לאחור \\ ובכל קשר וקשר תאמר אלו דברים
}

שטן עז Lo stringo e lego nel nome di il core di Tala filia di la tala

Come ela stenta fin'a che mio cor non contenta

ובחון ומנוסה
And make thirty-three knots in your hand backwards [or: behind your back?]

and with every knot and knot say the following words:

I tighten it and bind in the name of the mighty devil The heart of N.N., daughter of N.N.

How she struggles as long as she does not make my heart happy.

[It is both] tested [and] tried.

This kind of code-switching within one segulla, code-switching that includes a both a change of language and a change of script, is the only such case within this codex and is quite rare among magical manuscripts. ${ }^{48}$ Code-switching without changing the script, however, can be observed more often: it may happen that the instructional part of a segulla is, for instance, in Aramaic or Yiddish, while the spells to be pronounced or written down are in Hebrew. The Italian of the love charm in Cod. hebr. 252 points to the Northern Italian region of Veneto. With regard to content, it should be conceded that terming such spells 'love charms' might be regarded euphemistic, as they are mainly concerned with the unilateral exercise of power over another human being. ${ }^{49}$

\subsection{Astronomical and cosmological diagrams}

Apart from magical texts, the original compilation executed by hand A includes a number of diagrams and drawings, some of a more scientific nature, some of a more mystical-cosmological nature. Folio 12a, for example, contains an astronomical diagram that illustrates the four phases of the moon (Fig. 5). On top the sun is depicted with a face, whose rays of light strike the four moons in four different positions relative to the earth, which is right in the centre of the page. Below the diagram four spheres are labelled: שמים 'heaven', ארץ 'earth', מים 'water', and תהום 'abyss, underworld'. On earth and below the heavens we can

48 A different type of bilingual and multi-script manuscript can be found in Italian-Hebrew codices that contain every segulla in a Hebrew as well as an Italian version, e.g., the manuscripts Tel Aviv, Gross Family Collection, IT.011.016 (formerly 325) and New York, Jewish Theological Seminary, MS 1729; on the former see Bellusci 2018.

49 Such spells can thus be termed 'aggressive erotic magic'; cf. Bohak 2008, 123-135 and 153158. For a comprehensive account of Jewish love magic, see Saar 2017. 
make out what look like stylized humans. An almost identical diagram - though without the anthropomorphism of the sun - can be found in the much earlier geographical-astronomical work Tsurat ha-arets 'The form of the Earth' by Abraham bar Hiyya (c. 1070 - c. 1136), who was the first Jewish mathematician and astronomer to write scientific treatises in the Hebrew language..$^{50}$

In contrast to the diagram on fol. 12a, the scheme on fol. 8a delineates a broader cosmological notion (Fig. 6). This folio displays the different spheres of the cosmos with their respective celestial bodies: at the very top - four spheres potentially symbolizing four aspects of divine creation (from the top): אצילות 'nobility', בריאה 'creation', יצירה 'formation', and עשיה 'making'. Below them

- the גלגל חוזר 'returning wheel' with the twelve signs of the Zodiac spanning to the left and the right, and directly beneath them is the sphere of the fixed stars. Below the fixed stars we find, in descending order, the planets and the sun and at the very bottom there are the four elements, fire, wind, water, and earth. The scheme has slightly anthropomorphic features, with the ends of the uppermost four spheres giving the impression of the curls of a wig and with the spheres of the zodiac signs and the fixed stars reaching out like arms.

\section{3 'Non-Jewish’ magic}

On fols $6 \mathrm{~b}$ and $8 \mathrm{~b}$, hand $\mathrm{D}$ has added material that caught the attention of Moritz Steinschneider as well as that of rabbi and folklorist Max Grunwald. On fol. $6 \mathrm{~b}$, the scribe has written down two magical triangles or 'vanishing acts ${ }^{51}$ against fever; these triangles use the names אברקולס, possibly 'Abraqolas', and אברקלוע 'Abraqaloa'. The second is labelled by the scribe as an alternative version to the first: או על דרך זה 'or this way'. The triangles are accompanied by an incantation formula in the style of a liturgical supplication. The formula makes direct reference to the magical triangle and the way the magical formula is supposed to work:

50 E.g. the manuscript Munich, Bayerische Staatsbibliothek, Cod. hebr. 36, which contains Tsurat ha-arets, has the diagram on fol. 113a; cf. Busi 2005, 73-75. On Abraham bar Hiiyya, see Wigoder 2007.

51 In a magical triangle or vanishing act (in German Schwindeschema), a magic word or formula is written down, and in each line the word is repeated but subsequently reduced by one letter until only one letter is left. By symbolically erasing the word, an illness, typically fever, is believed to become eradicated from a sick person. See, e.g. Faraone 2012 on vanishing acts in Greek magical texts. 


\section{יהי רצון מלפניך יהוה אלהי ואלהי אבותי רבון העולמים כשם שהשם הזה הזה הולך

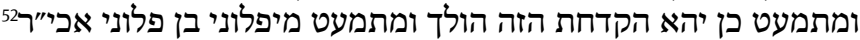

The formula is written in square script, which again indicates its efficacy, and is accompanied by a magical square..$^{53}$ On fol. $8 \mathrm{~b}$, the same scribe noted a segulla for a woman having difficulties during birth (Fig. 6). The instructions demand that magical names be written on kosher parchment as an amulet. What is referred to as names here is the so-called Latin Sator square 'sator arepo tenet opera rotas, ${ }^{54}$ but written in Hebrew letters, inserted directly beneath the instructions. As with the magical triangles on fol. $6 \mathrm{~b}$, the scribe gives an alternative version of the Sator square which also includes other instructions. The instructions and the second square are separated from the first by a thin line. The letters of the second square are written in a tabular grid, while the first square, written without a grid, is designed more in the shape of a column, with a vertical size larger than its horizontal size. The accompanying instructions do not demand the production of an amulet: או על זה הדרד או תלחוש באזנה אשמלית 'Or in this way. Or whisper in her left ear'. The only textual difference between the two squares is the spelling of the last letter of the fourth line or word, which in the Latin version of the palindrome is opera. The second square has an Aleph, while in the first square it seems that the Aleph was later altered to a $\mathrm{He}$. This alteration, however, breaks the symmetry of the palindromic square. In his catalogue entry for the manuscript, Steinschneider lists the content of these pages and adds 'auch sonst erkennt man den nichtjüdischen Ursprung sofort' ${ }^{55}$ The remark refers not only to these two pages but also to other parts of the manuscript and reflects Steinschneider's apologetic stance

52 Hamburg, Staats- und Universitätsbibliothek, Cod. hebr. 252, fol. 6b. 'May it be your will, Lord, our God and God of our fathers, ruler of the worlds: Just as this name is diminishing, so shall the fever of N.N. diminish. Amen! Let it be your will’ [or: אבי"ר 'Our Lord, our creator, our maker, our healer'].

53 On magical squares, see, e.g. Comes 2016. The defining feature of a magical square is that the sums of all its columns and all its rows (and usually also the diagonals) are equal.

54 The palindromic phrase, which is usually written in the form of a square, goes back to Roman Antiquity. It is ascribed hidden mystical meaning and magical efficacy; see Hofmann 1978.

55 Steinschneider 1969, 100: 'also elsewhere the non-Jewish origin is immediately apparent'. Scholem 1984, 97 n. 142, too, resolutely und unequivocally insists on the non-Jewish origin of the phenomenon of magical squares. Trachtenberg 1939, 296 n. 14, mentions our Cod. hebr. 252 as providing an example of magical squares in a Jewish manuscript. He also posits a nonJewish background for these squares, claiming that Jews adopted them from Christians, in particular from Agrippa von Nettesheim (see p. 143). 
with regard to Jews and magic. He regularly describes magical texts and practices both as 'non-Jewish' in origin and character, and as the result of Christian and Muslim influences on the Jews during the Middle Ages. ${ }^{56}$ The folklorist Grunwald also mentions the magical triangles on fol. $6 \mathrm{~b}$ of Cod. hebr. $252 .{ }^{57} \mathrm{In}$ contrast to Steinschneider, it seems that he does not intend to single out nonJewish elements in Jewish magical texts. On the contrary, he appears to acknowledge the syncretistic nature of magic and a potential Jewish influence on the formation of the magical name Abrasax that is also the supposed origin of אברקולס ‘Abraqolas', as found in our manuscript.

\subsection{A childbirth amulet containing the story of Elijah and Lilith}

On fols 18b and 19a, we find a well-known text for a Jewish childbirth amulet (Fig. 7). ${ }^{58}$ This version of the text, however, contains a passage near the end that is not to be found in most printed versions of this amulet, as they are known to us from Central Europe. Introduced by the description 'Poem for women in labour and [against] the evil eye. True and tried', the legend about an encounter of the prophet Elijah with the child-murdering demoness Lilith and her demonic entourage follows. ${ }^{59}$ Lilith tells the prophet that she is on her way to a woman and her newborn child to kill the infant. When Elijah threatens to bind Lilith with a ban, Lilith begs Elijah to let her go. She promises not to go after the woman and her child. In addition Lilith agrees to reveal her secret names to Elijah, and she swears that whenever in the future someone uses her names, neither she nor her minions will be able to harm the newborn or its mother. On fol. 19a, we see the fourteen names of Lilith, written in square script. At this point, the printed amulets usually go on with standard magical formulas for

56 See Steinschneider 2012, 591 and Veltri 2012.

57 Grunwald 1902, 122-123 n. 1. In the same article (p. 140), Grunwald also mentions Cod. hebr. 252 as containing an example of magical squares in a Jewish manuscript, though he does not remark on the supposed non-Jewish origin of the squares.

58 Printed Jewish childbirth amulets containing the story of the encounter between the prophet Elijah and the demoness Lilith, a story which is also found in our manuscript, Cod. hebr. 252, were ubiquitous in early modern Central Europe. On such amulets, see, e.g. Sabar 2002, 681682 and Folmer 2007. A comprehensive study of this type of printed Jewish amulet has yet to be written.

59 The myth of the demoness Lilith was fed by various sources. From the Middle Ages on, Lilith was established in Jewish folklore as the legendary first wife of Adam that is now roaming around as a demoness to strangle newborn children. On Lilith, see Scholem and Heschel 2007; on Lilith's threat to children, see Naveh and Shaked 1998, 111-122 and Veltri 2001. 
childbirth amulets and Psalm 121. Our manuscript, however, continues with an adjuration of Lilith by the prophet Elijah. This augmented textual version of the encounter is also known from other sources, though its evidence is rather scarce when compared to the version that lacks the adjuration. The adjuration is first found in print in a 1710 edition of David ben Aryeh Leib of Lida's ספר סוד הס 'Book of the Secret of the Lord'. ${ }^{60}$ The text can also be found in print in some nineteenth-century editions of the Psalms that include a treatise Mishpat Tsedeq. ${ }^{61}$ Our text furthermore appears in Montgomery's volume on Aramaic incantation texts from Nippur. ${ }^{62}$ Naveh and Shaked were able to identify the name of a beneficiary in Montgomery's text: 'Mercada, known as Vida'. ${ }^{63}$ The use of a name instead of a placeholder indicates that the text published by Montgomery derives from an amulet; the Spanish name itself points to a Sephardi context. And the names Mercada 'sold' and Vida 'life' likely point to the very same custom that might be attested by the name Abraham Mercado in our Cod. hebr. 252 on fol. 9b. ${ }^{64}$ Another full text of the Elijah-Lilith encounter, i.e. with Elijah's adjuration of Lilith, can be found in the collection of the Smithsonian National Museum of Natural History in a handwritten amulet from nineteenth-century Tunisia. ${ }^{65}$ All in all, we find that the printed Ashkenazi amulets usually do not feature the adjuration by Elijah as a second part of the amulet

60 David ben Aryeh Leib of Lida 1710, 20a. Kaspina 2014, 190, points to this source. David ben Aryeh Leib of Lida's (c. 1650-1696) Book of the Secret of the Lord deals with circumcision and customs associated with it. The amulet text including the adjuration is found on fol. 20a as the last part of a section of segullot and refu'ot. This section seems to have been appended to the main text of the book only in this specific Berlin edition of the book. It is neither part of the editio princeps (Amsterdam 1694) nor of any later edition that we were able to consult.

61 E.g. in Tehillim 'im sefer mishpat tsedeq 1830, 307 and Sefer tehillim [...] ve-gam sefer mishpat tsedeq $1877,148 \mathrm{~b}($ ?). Here an instruction says that the text should be written on parchment with ktav ashurit, lit. 'Assyrian script'. This term usually designates the Hebrew square script and occasionally even the ktav stam, the variant of the square script used for sacred writings such as Tora scrolls, tefillin, and mezuzot.

62 Montgomery 1913, 258-264 (no. 42). He had received the text from his colleague Richard Gottheil and sensed that it was not likely to come from an incantation bowl. However, he might not have been aware that he was dealing with a rather late, post-medieval text; see Scholem 1948, 166, n. 25.

63 Naveh and Shaked 1998, 118, n. 18.

64 See above, chapter 3.4. The presumable background of the name 'Mercada, known as Vida' was not addressed by Naveh and Shaked 1998, but it was addressed by Kaspina 2014, 198, who cites the lecture 'When Elijah Met Lilith-Magic Healing Incantations in Judeo-Spanish', which was delivered by Tamar Alexander at the Sixteenth World Congress of Jewish Studies in 2013.

65 Washington, DC, Smithsonian National Museum of Natural History, 217693. See Cohen Grossman 1997, 154-156. 
text ${ }^{66}$ while we have some evidence for the text in Ashkenazi printed books and in Sephardi or Mediterranean manuscript amulets. The manuscript Cod. hebr. 252 has a slightly abridged version of the adjuration (fol. 19a):

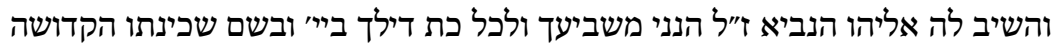

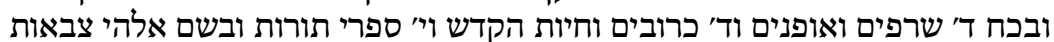

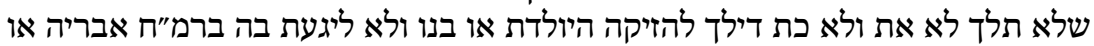

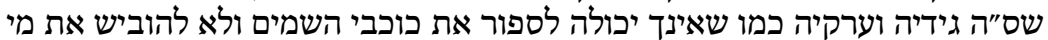

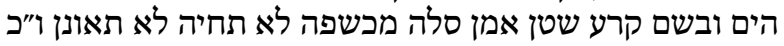

And Elijah replied to her [i.e. Lilith], I adjure you and all of your class, by the Lord and by the name of his holy Shekhina, and by the power of the four Serafim and Ofanim and the four Cherubs and the Holy Beasts, the ten books of teaching, and in the name of the Lord of Hosts: that you will not go, neither you nor those of your class, to harm the woman in labour or her child, and that you will not afflict her, her $248 \mathrm{limbs}$, and her 365 tendons and bands, as you are able neither to count the stars in the sky nor to dry the waters of the sea. With the name qera' satan. Amen, sela. 'You shall not let a sorceress live' (Ex 22:17) [...].

With the inclusion of the Elijah and Lilith episode, Cod. hebr. 252 features an expanded version of one of the most prominent amulet texts of Jewish childbirth magic. This expanded version is attested much less frequently than the standard version, and in particular appears only rarely in actual amulets. The expanded version's general transmission history invites more thorough inspection by future researchers.

\section{Guest content, with a Sabbatean background}

Besides the magical and mystical-cosmological texts, which are the corecontent of the manuscript, Cod. hebr. 252 contains additional material, which can be considered guest content, namely, the poetic texts on fols $1 \mathrm{~b}$ (Fig. 2) and 33b, and the lists of towns and people on fol. 32b (Fig. 8), the latter being written upside-down. ${ }^{67}$ The poems use a variant of the acrostic: certain lines are

66 Kaspina 2014, 201, ascertains the same finding for Eastern European amulets from the nineteenth century.

67 On the terms 'guest text' or 'guest content', see Gumbert 2004, 32 and 42 and Ciotti et al. 2018, 1 and 3. Gumbert's definition of a guest text as content that has been 'added, as an enrichment into an existing codicological unit' is mostly temporal and structural. As understood by Ciotti et al. guest content can be distinguished from core-content and especially from paracontent by not being linked or related at all to the manuscript's core-content and by not 
marked by thin strokes. On fol. 1b, the initial letters of the marked lines spell out ' שבתי חז, שתי חזק Sabbatai is strong'. In the poem on fol. 33b, the marked lines spell out שבתי חי חי 'Sabbatai lives'. Steinschneider interpreted this notation as referring to Sabbatai Zevi, an alleged Jewish messiah. ${ }^{68}$ His appearance and activities in 1665 and 1666 caused an uproar in all major Jewish communities in Europe and the Mediterranean area. After being imprisoned by the Ottoman authorities, his subsequent conversion to Islam left most of his followers in shock. The Sabbateans, i.e. those adhering to the belief in Sabbatai even after his death in 1676, interpreted his apostasy as part of a mystical plan for the redemption of the world and were regarded as heretics by mainstream Judaism. ${ }^{69}$ Because of the acrostic referring to the name Sabbatai, Steinschneider supposed that the scribe of this guest content was such a Sabbatean. ${ }^{70}$ As the lists of towns and names found on fol. 32b seem to have been written by the same hand as the poems, Steinschneider speculated the possibility that a Sabbatean traveller had noted down Sabbateans that were living in various places. ${ }^{71}$ The page contains four lists of towns. The lists are divided from each other by lines drawn with ink. The first list represents a journey down the Rhine starting in Frankfurt am Main and ending in Kleve in the Lower Rhine region. The second list consists mostly of

providing any substantial data on the manuscript. In this respect, content that was added to a manuscript later can be part of the core-content, if it thematically matches the original corecontent. The texts added to the manuscript Cod. hebr. 252 by hands $\mathrm{C}$ (fol. $4 \mathrm{a}-\mathrm{b}$ : a childbirth amulet and a segulla to calm a storm at the sea) (Fig. 3) and E (fol.16b: instructions for the preparation of a ritual) concern magic and can therefore be considered core-content. The content added by hand B (fols $1 \mathrm{~b}, 32 \mathrm{~b}, 33 \mathrm{~b}$ : the poems and lists of towns with names of persons) does not relate to magic nor does it provide specific data on the manuscript itself. This content is therefore to be regarded as guest content. This determination would still be true if hands B, C and $\mathrm{E}$ were all the same scribe, which may be the case, as these hands are quite similar.

68 On Sabbatai Zevi, see Scholem 1973.

69 In the Jewish history of Hamburg, there is a particularly noteworthy episode concerning Sabbateanism. During his time as the chief rabbi of the triple community Altona-HamburgWandsbek, Rabbi Jonathan Eybeschütz (1690-1764) faced accusations by his adversary Jacob Emden (1697-1776) that certain amulets Eybeschütz had issued were of Sabbatean origin and that he himself was a Sabbatean. In the course of what is now known as the Emden-Eybeschütz controversy, Emden even had to leave Altona for some time since Eybeschütz was popular among the Jewish community. Even the Christian authorities, wishing to prevent any upheaval, tended to act in favour of Eybeschütz. On this controversy, see, e.g. Maciejko 2017. Our manuscript Cod. hebr. 252, however, most likely is not to related to these Hamburg events.

70 Even though Sabbatai Zevi was the most prominent one, he was certainly not the only bearer of this name.

71 See Steinschneider 1969, 100. 
towns in Franconia but ends with Frankfurt. The fourth list also contains four towns in Franconia, but more to the south-east of those in the second list. We have not yet been able to precisely identify the places of the third list. Some names of towns are followed by the name of a person, all male except for one. The names are given names only, without patronym. Often, they are preceded by 'ר for rav 'master, teacher, rabbi', and sometimes by ' $\Pi$ for hakham 'sage, wise man'. In some cases, a name is followed by the adjectives עשיר 'wealthy' or זיקו 'old, esteemed'. A query for these names with their respective places in the Epidat Research Platform for Jewish Epigraphy did not produce a match with existing entries in the database. ${ }^{72}$

While at this point the purpose of the lists and the circumstances under which they were written must remain a matter of speculation, these lists do add a local and personal dimension to the manuscript Cod. hebr. 252, a dimension that is not often found in magical texts. We are nevertheless unable to determine whether these lists stand in any relation at all to the magical strata. If these lists, as supposed by Steinschneider, were indeed written by the same hand as the Sabbatean poems (and if these poems are indeed Sabbatean), a terminus post quem for the lists and the poems would be 1666, the year of Sabbatai Zevi's dramatic rise and fall.

\section{Conclusion: A short history of Cod. hebr. 252}

The presumably Sabbatean guest texts help to contextualize Cod. hebr. 252 in a time and locale, especially since the manuscript does not feature substantial paracontent, such as a colophon, that might otherwise provide such information. But what else can we ascertain about the life of the manuscript, its production, and use?

Based on the script and, above all, on the linguistic features of the Italian in the bilingual spell on fol. 17b, the parts of the manuscript that belong to the original production plan and were executed by hand A can be located in Northern Italy, probably Veneto. It can be supposed that the original manuscript was produced in this region. Analysis of the codex does not reveal any concluding features that would allow us to date these original parts of the manuscript more precisely than to the seventeenth century, as already suggested by Steinschneider. Based on the contents written by hand A, it is obvious that the project of the

$72<$ http://www.steinheim-institut.de/cgi-bin/epidat> (accessed on 14 Dec. 2020). 
original scribe was not to compose a mere handbook or manual of magic that would contain only practical knowledge. Rather, these parts of the codex mirror the broad, multifaceted interests of this owner-scribe and his ambition to create a universal compendium that was not limited to esoteric knowledge. Besides noting down magic proper, i.e. recipes and instructions for specific purposes such as protection, finding lost items, or against fever - which still makes up the largest part of the manuscript - the scribe arranged magical names in diagrams, made mystical-cosmological drawings, and copied scientific-astronomical illustrations.

Because the scribe included text numbers in the margin, it is highly likely that he produced (or at least intended to do so) some kind of table of contents or index. Although he numbered the manuscript's texts - which would make the overall structure of its content less open to additions - he left a lot of pages blank, both in between items as well as, presumably, at the end of the original manuscript. These blank pages were an invitation for additional content, a phenomenon that can be viewed as an affordance. We do not know if the creation of this affordance was intended by the scribe. Nevertheless he must have been aware that later owners could fill these spaces with content, or he may even have intended to do so himself on occasion. Subsequently, later Sephardic hands added material that matched the topics of the existing texts, e.g. the childbirth amulets for protection against Lilith; the result of this process is a temporally layered manuscript. It cannot be determined where the manuscript was when the various additions of magical texts by Sephardic hands were made, since Sephardim lived and travelled in various parts of Europe. At some point in its history, however, the manuscript was brought from Northern Italy to the German area. The guest content, i.e. the lists of towns located mostly in the Middle Rhine area and Franconia in combination with the Sabbatean poems by the same hand, indicates that the manuscript was in the German lands when this guest content was incorporated into the manuscript. The references to Sabbatai Zevi would date this incorporation to the second half of the seventeenth century. But the manuscript was still in Jewish hands then.

In the list of towns on fol. 32b, Frankfurt is mentioned twice and is situated quite centrally amidst the other towns that we could identify. This proximity to Frankfurt could then be the next step in the manuscript's life, i.e. the acquisition by the Frankfurt-based collector Zacharias Konrad von Uffenbach. We may suppose that Uffenbach bought the manuscript in the early eighteenth century, 
as it is included already in Mai's catalogue, which was published in $1720 .{ }^{73}$ At some point in time between becoming part of Uffenbach's collection and being catalogued by Moritz Steinschneider in the 1870s, the manuscript lost many of its folios, though the precise number of them cannot be determined. The reworking of a former explicit into a new title page can be interpreted as an attempt to heal these wounds.

As unique as Cod. hebr. 252 is in the specific compilation of its primary content, paracontent, and guest content, the manuscript can nevertheless be considered a rather typical case of a Jewish magical MTM from early modern Europe: this manuscript started as the project of a single scribe, most likely for his own purposes. In the course of time, further layers of content accumulated, added by later owners and users. Our manuscript illustrates that Jewish manuscripts - and Jewish magical manuscripts in particular - often have a rich history of migration. The syncretistic, magical-mystical content comprises 'genuine' Jewish magic as well material that is common to the magical traditions of many Jewish and non-Jewish cultures in Europe and the Mediterranean. At the same time, the manuscript's fragmentary state and the scarcity of hard facts deducible from its paracontent makes it currently impossible for us to draw a definitive picture of the manuscript and its history. That said, our examination of Cod. hebr. 252 was also intended to illustrate that scholarly research on magical Hebrew manuscripts from the Staats- und Universitätsbibliothek Hamburg as a whole is still in its beginnings, and there is much more to be discovered.

\section{Acknowledgements}

The research for this article was funded by the Deutsche Forschungsgemeinschaft (DFG, German Research Foundation) under Germany's Excellence Strategy - EXC 2176 'Understanding Written Artefacts: Material, Interaction and Transmission in Manuscript Cultures', project no. 390893796, and prior to that in the SFB 950 'Manuscript Cultures in Asia, Africa and Europe'. The research was conducted within the scope of the Centre for the Study of Manuscript Cultures (CSMC) at Universität Hamburg. We thank the anonymous reviewers, as well as Jörg B. Quenzer (Hamburg), Caroline Macé (Hamburg), and Ulrike Hirschfelder (Potsdam) for their comments on the earlier drafts of this paper.

73 On Uffenbach's acquisition of Hebraica, see Franke 1967, 62-69. Uffenbach's correspondence does not reveal the name of the Jewish manuscript dealer from whom he received large parts of his Hebrew manuscript collection. 


\section{References}

Bausi, Alessandro, Michael Friedrich, and Marilena Maniaci (eds) (2019), The Emergence of Multiple-Text Manuscripts (Studies in Manuscript Cultures, 17), Berlin: De Gruyter.

Ben-Ami, Issachar (2003), 'Beliefs and Customs', in Reeva Spector Simon, Michael Menachem Laskier and Sara Reguer (eds), The Jews of the Middle East and North Africa in Modern Times, New York: Columbia University Press, 180-203.

Beit-Arié, Malachi (1993a), Hebrew Manuscripts of East and West: Towards a Comparative Codicology, London: The British Library.

Beit-Arié, Malachi (1993b), The Makings of the Medieval Hebrew Book: Studies in Palaeography and Codicology, Jerusalem: Magnes.

Beit-Arié, Malachi (2020), Hebrew Codicology: Historical and Comparative Typology of Hebrew Medieval Codices based on the Documentation of the Extant Dated Manuscripts Using a Quantitative Approach, Preprint internet English version 0.4 (February 2020) <https://web.nli.org.il/sites/NLI/English/collections/manuscripts/hebrewcodicology/ Documents/Hebrew-Codicology-continuously-updated-online-version-ENG.pdf> (accessed on 2 July 2021).

Bellusci, Alessia (2018), 'Jewish Magia in Renaissance and Baroque Italy: Preliminary Notes on Ms. GFC 325', in Flavia Buzzetta (ed.), Cabbala (Cahiers Accademia, 11), Lucca: San Marco Litotipo, 23-42.

Bohak, Gideon (2008), Ancient Jewish Magic: A History, Cambridge: Cambridge University Press. Busi, Giulio (2005), Qabbalah visiva, Turin: Einaudi.

Ciotti, Giovanni, Michael Kohs, Eva Wilden, Hanna Wimmer and the TNT Working Group (2018), 'Definition of Paracontent' <http://www.manuscript-cultures.uni-hamburg.de/papers_ e.html (accessed on 14 Dec. 2020).

Cohen Grossman, Grace (1997), Judaica at the Smithsonian: Cultural Politics as Cultural Model (Smithsonian Studies in History and Technology, 52), Washington, D.C.: Smithsonian Institution Press.

Comes, Rosa (2016), ‘The Transmission of Azarquiel’s Magic Squares in Latin Europe', in Faith Wallis and Robert Wisnovsky (eds), Medieval Textual Cultures: Agents of Transmission, Translation and Transformation (Judaism, Christianity, and Islam - Tension, Transmission, Transformation, 6), Berlin: De Gruyter, 159-198.

David ben Aryeh Leib of Lida (1710), Sefer sod ha-shem ספר סוד ה', Berlin: s.n.

Daxelmüller, Christoph (2010), 'Hamburg, Wien, Jerusalem. Max Grunwald und die Entwicklung der jüdischen Volkskunde zur Kulturwissenschaft 1898 bis 1938', in Johler and Staudinger (eds.) 2010, 375-393 [= Österreichische Zeitschrift für Volkskunde, LXIV/113: 375-393].

Faraone, Christopher A. (2012), Vanishing Acts on Ancient Greek Amulets: From Oral Performance to Visual Design (Bulletin of the Institute of Classical Studies Supplement, 115), London: Institute of Classical Studies.

Folmer, Margaretha (2007), 'A Jewish Childbirth Amulet for a Girl', in: Martin F.J. Baasten and Reinier Munk (eds), Studies in Hebrew Literature and Jewish Culture (Amsterdam Studies in Jewish Thought, 12), Dordrecht: Springer, 41-56.

Franke, Konrad (1967), 'Zacharias Conrad von Uffenbach als Handschriftensammler. Ein Beitrag zur Kulturgeschichte des 18. Jahrhunderts’, Archiv für Geschichte des Buchwesens, 7: 1-208. 
Friedrich, Markus and Monika E. Müller (eds) (2020) Zacharias Konrad von Uffenbach. Büchersammler und Polyhistor in der Gelehrtenkultur um 1700 (Wissenskulturen und ihre Praktiken, 4), Berlin: De Gruyter.

Friedrich, Michael and Cosima Schwarke (eds) (2016), One-Volume Libraries: Composite and Multiple-Text Manuscripts (Studies in Manuscript Cultures, 9), Berlin: De Gruyter.

Grunwald, Max (1898), 'Zu “Eingänge”', Mitteilungen der Gesellschaft für Jüdische Volkskunde, 2: 79-81.

Grunwald, Max (1900), 'Aus Hausapotheke und Hexenküche', Mitteilungen der Gesellschaft für Jüdische Volkskunde, 5: 1-87.

Grunwald, Max (1902), 'Bilder und Zeichen auf jüdischen Denkmälern', Mitteilungen der Gesellschaft für Jüdische Volkskunde, 10: 121-144.

Guggenheimer, Heinrich W. and Eva H. Guggenheimer (1992), Jewish Family Names and Their Origins: An Etymological Dictionary. Hoboken: Ktav.

Gumbert, J. Peter (2004), 'Codicological Units: Towards a Terminology for the Stratigraphy of the Non-Homogeneous Codex', Segno e testo, 2: 17-42.

Harari, Yuval (2017), Jewish Magic Before the Rise of Kabbalah, Detroit: Wayne State University Press.

Harari, Yuval (2019), “'Practical Kabbalah” and the Jewish Tradition of Magic', Aries - Journal for the Study of Western Esotericism, 19: 38-82.

Hofmann, Heinz (1978), 'Satorquadrat', in Paulys Realencyclopädie der classischen Altertumswissenschaft, supplementary vol. XV, München: Druckenmüller, 478-565.

Johler, Birgit and Barbara Staudinger (eds) (2010), Ist das Jüdisch? Jüdische Volkskunde im historischen Kontext, Vienna: Österreichisches Museum für Volkskunde [offprint of Österreichische Zeitschrift für Volkskunde LXIV/113 (2010): 369-654].

Kaganoff, Benzion C. (2005), A Dictionary of Jewish Names and Their History. Lanham: Rowman \& Littlefield [1st edn: New York: Schocken, 1977].

Kaspina, Marina (2014), 'Заговоры от Лилит на ашкеназских амулетах для роженицы и младенца (XVIII-XX вв.)' in Olga Vladislavovna Belova et al. (eds), Круг жизни в славянской и еврейской культурной традичии, Moscow: s.n., 184-206.

Kohs, Michael (2016), “'For it has already been stolen from, soiled and dishonoured”, in Andreas Janke (ed.), Manuscript of the Month 2016.03, SFB 950: Hamburg <http://www.manuscript-cultures.uni-hamburg.de/mom/2016_03_mom_e.html> (accessed 14 Dec. 2020).

Leicht, Reimund (2006), Astrologumena Judaica: Untersuchungen zur Geschichte der astrologischen Literatur der Juden (Texts and Studies in Medieval and Early Modern Judaism, 21), Tübingen: Mohr Siebeck.

Leicht, Reimund and Gad Freudenthal (eds) (2012), Studies on Steinschneider. Moritz Steinschneider and the Emergence of the Science of Judaism in Nineteenth-Century Germany (Studies in Jewish History and Culture, 33), Leiden: Brill.

Maciejko, Pawel (2017), ‘Emden-Eybeschütz Controversy', in Dan Diner (ed.), Encyclopedia of Jewish History and Culture Online, Leiden: Brill <http://dx.doi.org/10.1163/2468-8894_ ejhc_COM_0201>.

Mai, Johann Heinrich (1720), Bibliotheca Uffenbachiana Mssta seu Catalogus et Recensio Msstorum Codicum Qui in Bibliotheca Zachariae Conradi ab Uffenbach, 1st Part: Bibliothecae Uffenbachianae Mstae Partes Tres Priores, Quibus Codices Ebraico-Rabbinici, Halle: Neue Buchhandlung. 
Malavasi, Stefania (2005), Tra diavolo e acquasanta: eretici, maghi e streghe nel Veneto del Cinque-Seicento (Saggistica, 10), Minelliana: Rovigo.

Montgomery, James A. (1913), Aramaic Incantation Texts from Nippur (University of Pennsylvania, The Museum, Publications of the Babylonian Section, 3), Philadelphia, PA: University Museum.

Mulsow, Martin (2005), 'Johann Christoph Wolf (1683-1739) und die verbotenen Bücher in Hamburg', in Johann Anselm Steiger (ed.), 500 Jahre Theologie in Hamburg. Hamburg als Zentrum christlicher Theologie und Kultur zwischen Tradition und Zukunft (Arbeiten zur Kirchengeschichte, 95), Berlin: De Gruyter, 81-111.

Naveh, Joseph and Shaul Shaked (1998), Amulets and Magic Bowls: Aramaic Incantations of Late Antiquity, 3rd edn, Jerusalem: Magnes.

Otto, Bernd-Christian and Stausberg, Michael (2013), 'General Introduction' in Bernd-Christian Otto and Michael Stausberg (eds), Defining Magic. A Reader, Sheffield: Equinox, 1-13.

Rebiger, Bill (2005), 'Zur Redaktionsgeschichte des “Sefer Razi'el ha-Mal'akh”', Frankfurter Judaistische Beiträge, 32: 1-22.

Rebiger, Bill and Peter Schäfer (eds) (2009), Sefer ha-Razim I und II - Das Buch der Geheimnisse I und II, 2 vols: vol. 1 Edition (Texts and Studies in Ancient Judaism, 125), vol. 2 Einleitung, Übersetzung und Kommentar (Texts and Studies in Ancient Judaism, 132), Tübingen: Mohr Siebeck.

Róth, Ernst and Hans Striedl (1984), Die Handschriften der Sammlung H. B. Levy an der Staatsund Universitätsbibliothek Hamburg (Verzeichnis der orientalischen Handschriften in Deutschland, 6, Hebräische Handschriften, 3), Stuttgart: Steiner.

Saar, Ortal-Paz (2017), Jewish Love Magic: From Late Antiquity to the Middle Ages (Magical and Religious Literature of Late Antiquity, 6). Leiden: Brill.

Sabar, Shalom (2002), 'Childbirth and Magic: Jewish Folklore and Material Culture' in David Biale (ed.), Cultures of the Jews: A New History, New York, NY: Schocken, 670-722.

Scholem, Gershom (1948), 'New Chapters in the Story of Ashmedai and Lilith (hebr.)', Tarbiz, 19: 160-175.

Scholem, Gershom (1973), Sabbatai Șevi: The Mystical Messiah, 1626-1676 (Bollingen Series, 93), Princeton: Princeton University Press.

Scholem, Gershom (1984), 'Alchemie und Kabbala', in Gershom Scholem, Judaica 4 (Bibliothek Suhrkamp, 831), Frankfurt am Main: Suhrkamp, 19-128.

Scholem, Gershom and Susannah Heschel (2007), 'Lilith', in Michael Berenbaum und Fred Skolnik (eds), Encyclopaedia Judaica, 2nd edn, Detroit: Macmillan, vol. 13, 17-20.

Schreuder, Yda (2019), Amsterdam's Sephardic Merchants and the Atlantic Sugar Trade in the Seventeenth Century, Cham: Palgrave Macmillan.

Schwartz, Dov (2005), Studies on Astral Magic in Medieval Jewish Thought (The Brill Reference Library of Judaism, 20), Leiden: Brill.

Sefer tehillim [...] ve-gam sefer mishpat tsedeq ספר תהלים [...] וגם ספר משפט צדק, Lemberg: Pessel Balaban, 1877.

Steinschneider, Moritz (1969), Catalog der hebräischen Handschriften in der Stadtbibliothek zu Hamburg und der sich anschliessenden in anderen Sprachen, Hildesheim: Olms [1st edn: Hamburg: Meissner, 1878].

Steinschneider, Moritz (2012), 'Der Aberglaube', in Leicht and Freudenthal (eds) 2012, 569-592 [1st edn: Der Aberglaube. Vortrag im Verein junger Kaufleute zu Berlin (1863). Für den Abdruck erweitert, Hamburg: Verlagsanstalt und Druckerei U. G. (vormals J. F. Richter), Königliche Hofbuchhandlung, 1900].

Stork, Hans-Walter (2014), 'The History of the Hebraica Collection', manuscript cultures, 6: 13-24. 
Tanakh: A New Translation of the Holy Scriptures, According to the Traditional Hebrew Text, Philadelphia, PA: The Jewish Publication Society, 1985.

Tehillim 'im sefer mishpat tsedeq תהלים עם ספר משפט צדק, Wroctaw (?): s.n., 1830.

Trachtenberg, Joshua (1939), Jewish Magic and Superstition: A Study in Folk Religion, New York: Atheneum.

Veltri, Giuseppe (1997), Magie und Halakha. Ansätze zu einem empirischen Wissenschaftsbegriff im spätantiken und frühmittelalterlichen Judentum (Texts and Studies in Ancient Judaism, 62), Tübingen: Mohr.

Veltri, Giuseppe (2001), 'The Meal of the Spirits, the Three Parcae and Lilith: Apotropaic Strategies for Coping with Birth Anxieties and Child Mortality', Henoch, 23: 343-359.

Veltri, Giuseppe (2012), 'Steinschneider's Interstitial Explanation of Magic', in Leicht and Freudenthal (eds) 2012, 233-246.

Wandrey, Irina (ed.) 2014, Ausstellungskatalog 'Tora - Talmud - Siddur'. Hebräische Handschriften der Staats- und Universitätsbibliothek Hamburg, Hamburg: SFB 950 [= manuscript cultures, 6].

Wigoder, Geoffrey (2007), 'Abraham bar Ḥiyya', in Michael Berenbaum und Fred Skolnik (eds), Encyclopaedia Judaica, 2nd edn, Detroit: Macmillan, vol. 1, 292-294.

Wolf, Johann Christoph (1727), Bibliothecæ Hebrææ Volumen III: Complectens Accessiones et Emendationes, ad Volumen Primum Totum, et Partem Secundi, Quoad de Scriptis Anonymis Exponit, Pertinentes, Hamburg: Felginer.

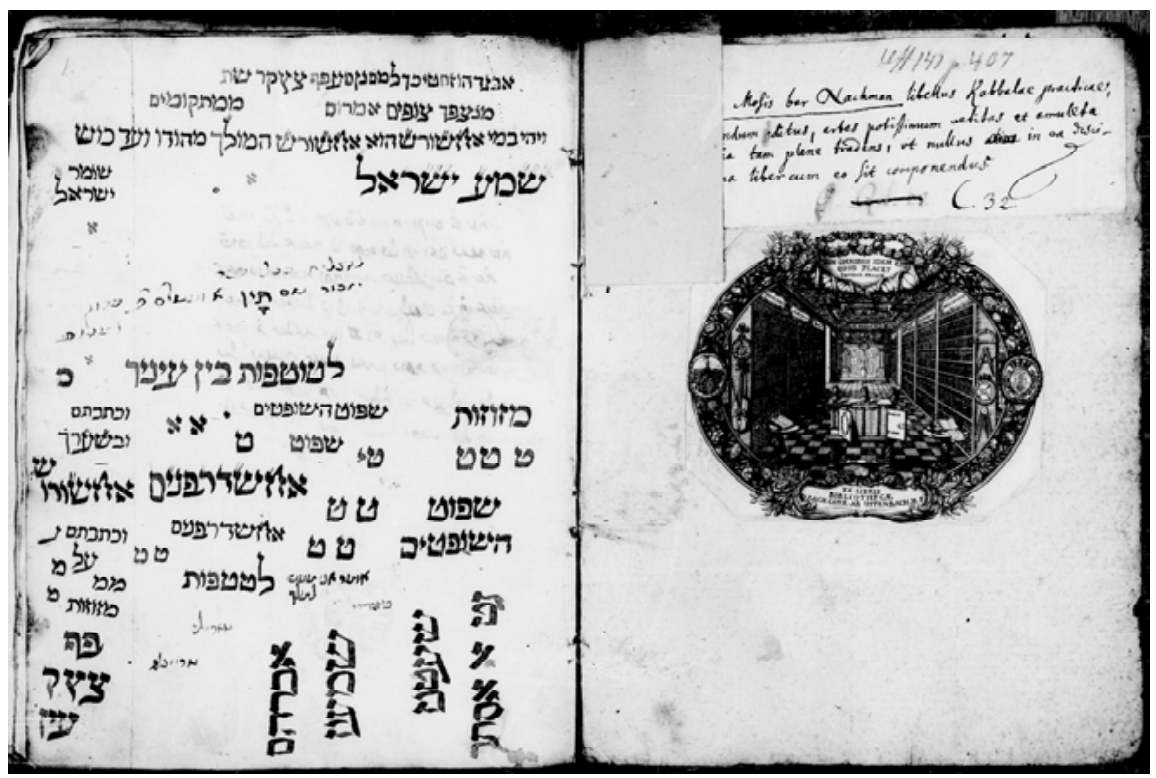

Fig. 1: Hamburg, Staats- und Universitätsbibliothek, Cod. hebr. 252, inner front cover (right) and fol. 1a (left). All pictures (Figs 1-8) are under Creative Commons Licence: CC BY-SA 4.0: <https://creativecommons.org/licenses/by-sa/4.0/>.

Figs 1-7: 〈https://resolver.sub.uni-hamburg.de/kitodo/PPN873729153〉. 


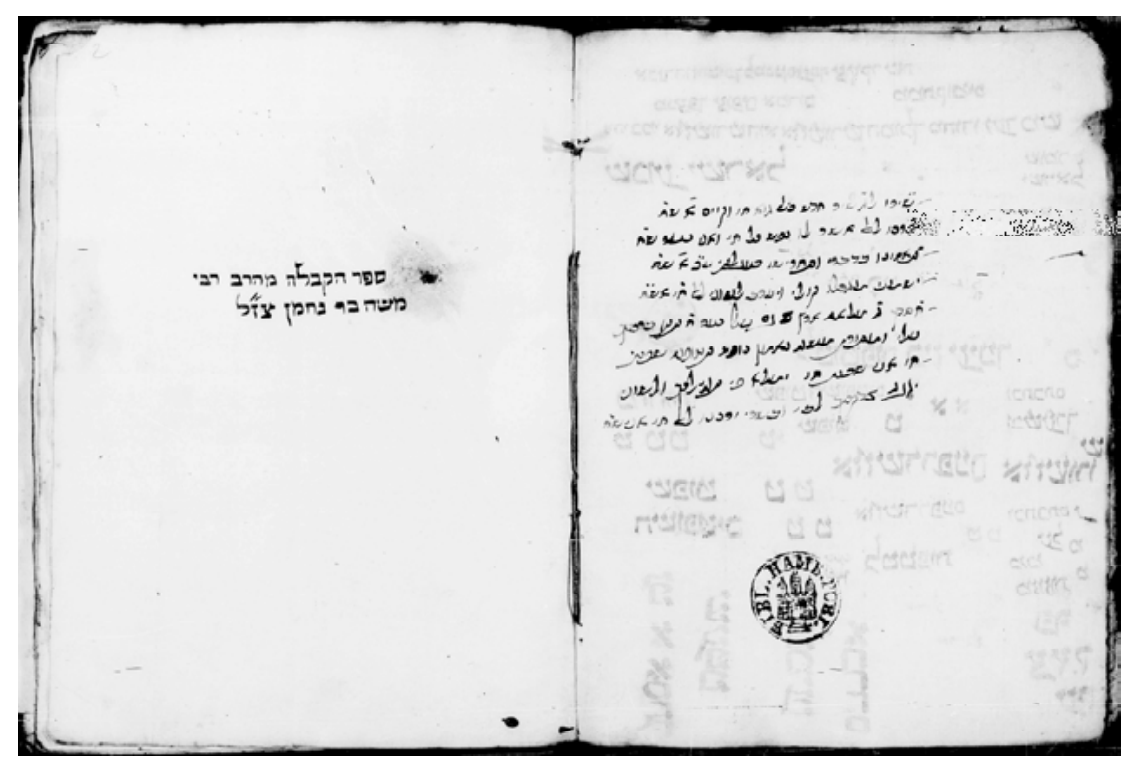

Fig. 2: Staats- und Universitätsbibliothek Hamburg, Cod. hebr. 252, fol. 1b (right, poem referring to Sabbatai Zevi), 2a (left, an explicit that was reworked into a title).



Fig. 3: Staats- und Universitätsbibliothek Hamburg, Cod. hebr. 252, fol. 3b (right, segullot nos 90-95), fol. 4a (left, childbirth amulet with an adjuration against Lilith). 


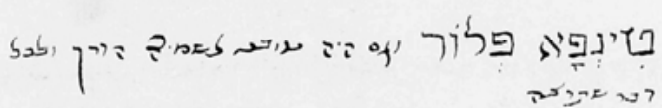



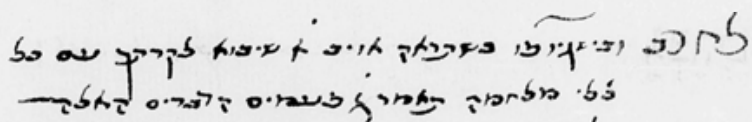

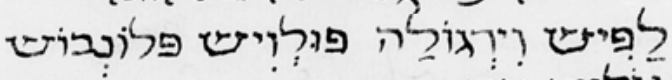
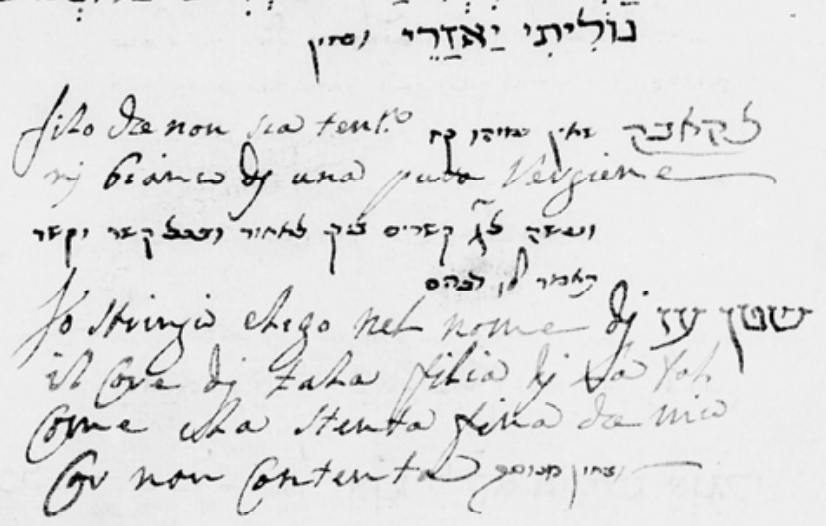

Fig. 4: Staats- und Universitätsbibliothek Hamburg, Cod. hebr. 252, fol. 17b (the last numbered segullot; at the bottom a segulla in Hebrew and Italian). 


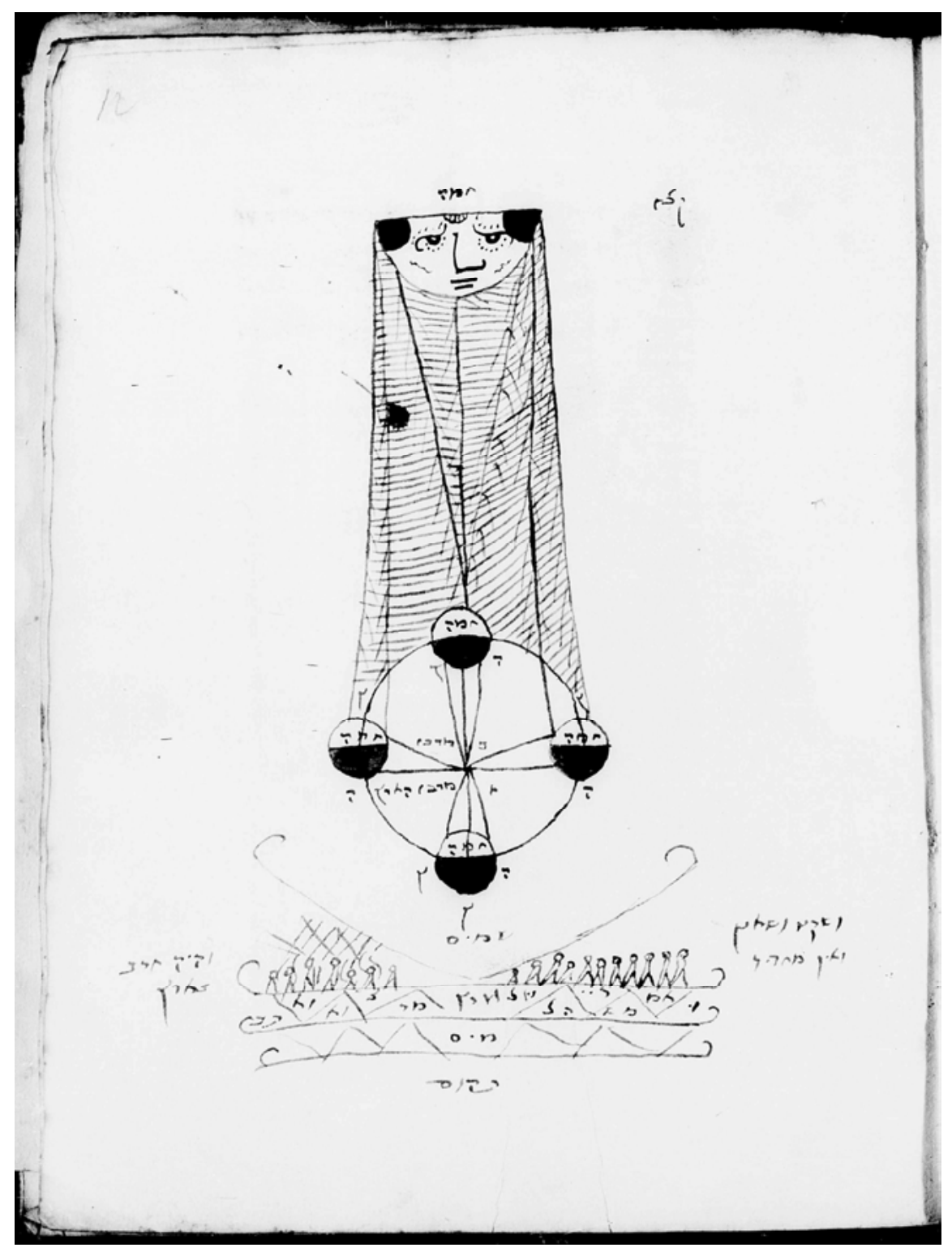

Fig. 5: Staats- und Universitätsbibliothek Hamburg, Cod. hebr. 252, fol. 12a (astronomical diagram explaining the four phases of the moon). 


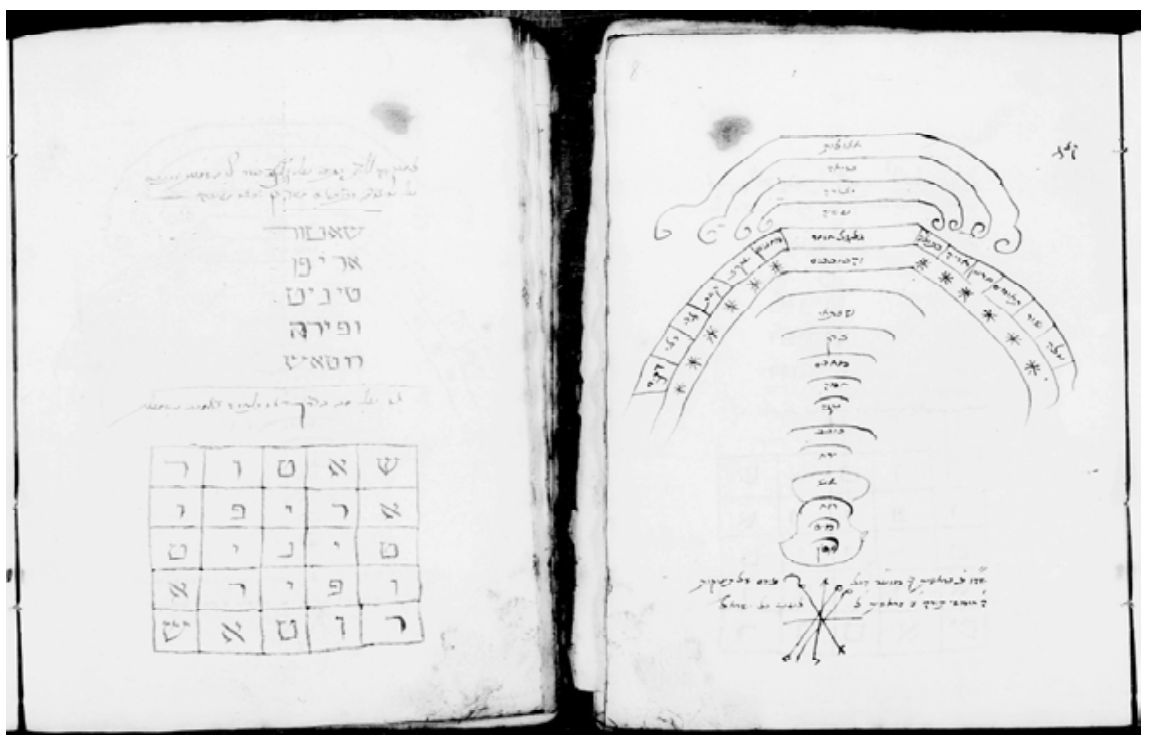

Fig. 6: Staats- und Universitätsbibliothek Hamburg, Cod. hebr. 252, fol. 8a (right, cosmological diagram), fol. 8b (left, Sator squares for a woman having difficulties during childbirth).

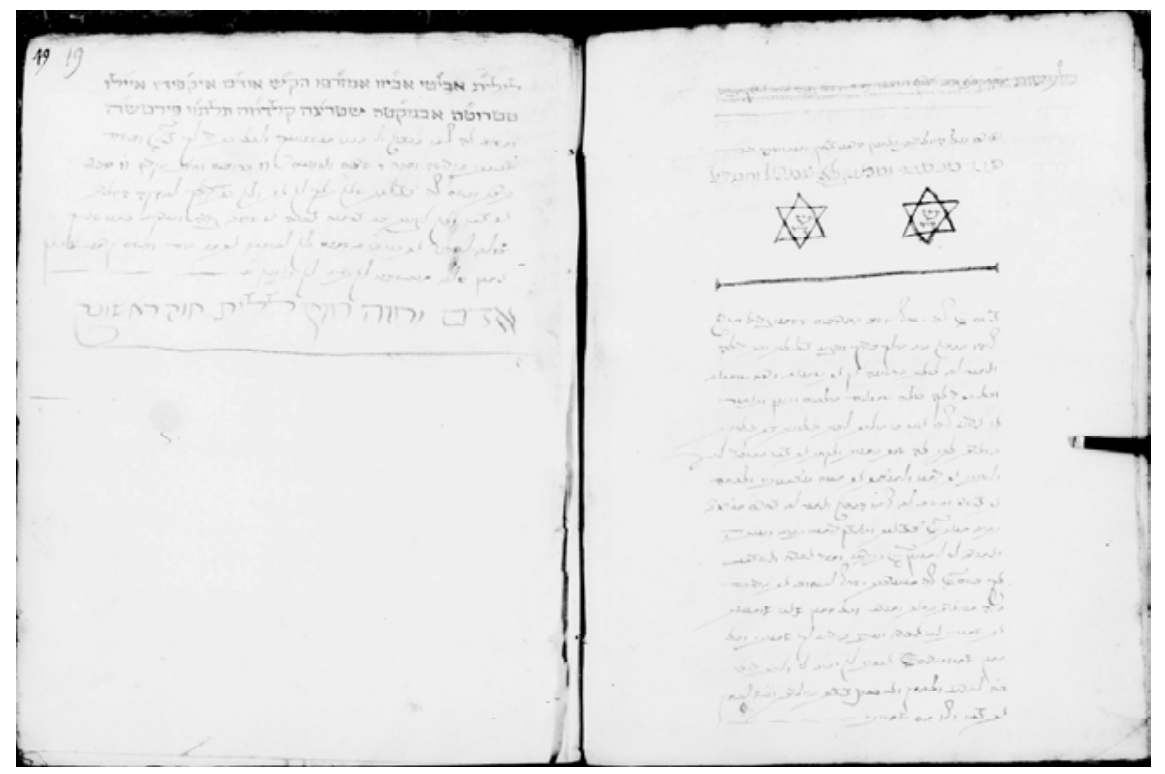

Fig. 7: Staats- und Universitätsbibliothek Hamburg, Cod. hebr. 252, fol. 18b (right), 19a (left), childbirth amulet with the story of the prophet Elijah and the demoness Lilith. 


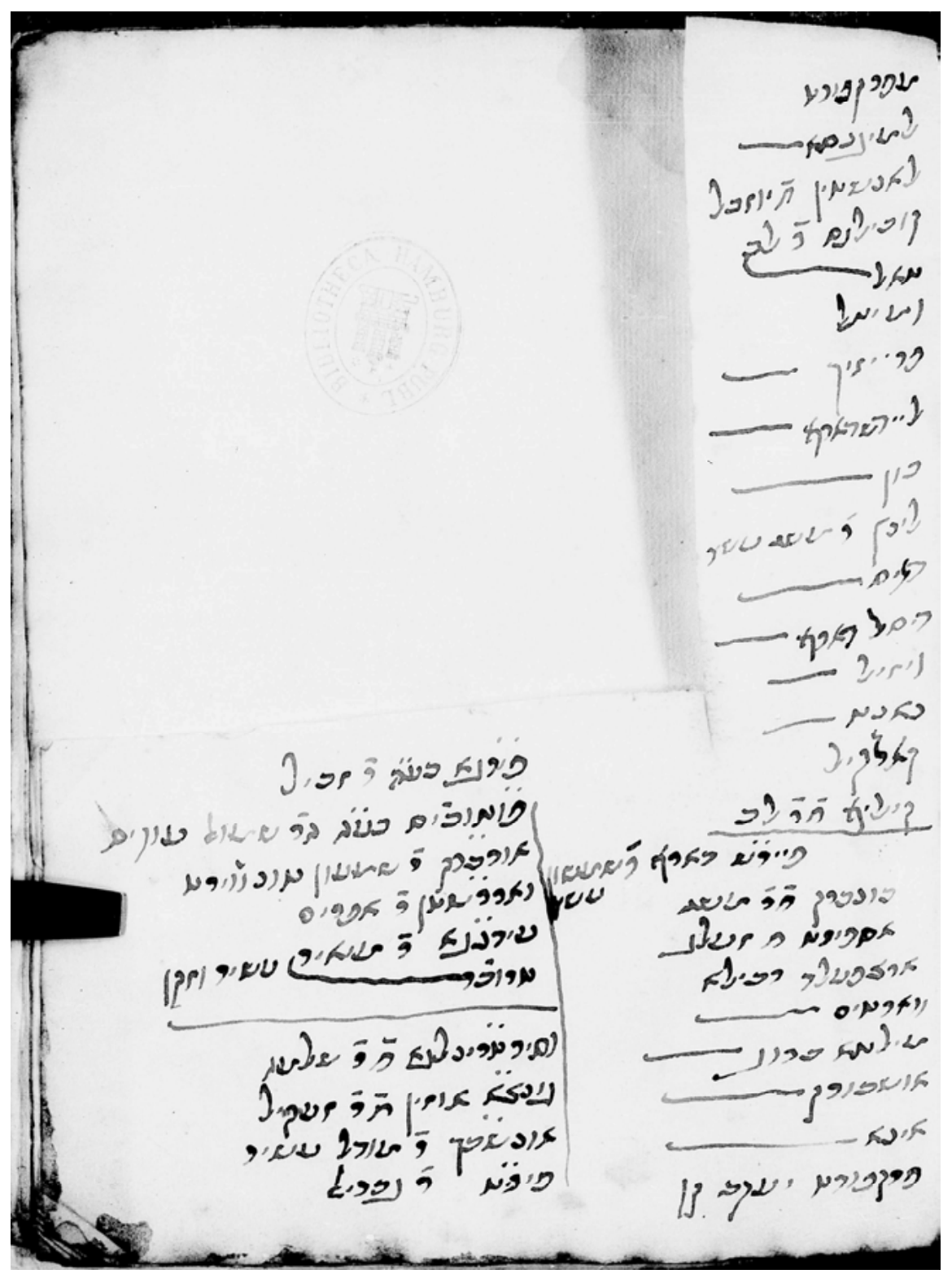

Fig. 8: Staats- und Universitätsbibliothek Hamburg, Cod. hebr. 252, fol. 32b, lists of places, sometimes accompanied by names of persons; turned 180 degrees. 〈https://resolver.sub.uni-hamburg.de/kitodo/PPN873729269〉. 